UDK: $347.51(497.5)$

$343.537: 347.513$

Pregledni znanstveni rad Primljen: 14. svibnja 2018.

Prihvaćen: 13. lipnja 2018.

Jure PLEĆC $\check{\text { S, }}$

doktorand Pravnog fakulteta Sveučilišta u Mostaru

jure-plecas@hotmail.com

\title{
PROFESIONALNA ODGOVORNOST JAVNIH BILJEŽNIKA U REPUBLICI HRVATSKOJ - STEGOVNA, KAZNENA, PREKRŠAJNA I GRAĐANSKOPRAVNA
}

Sažetak: Prema članku 2. Zakona o javnom bilježništvu, javnobilježničku službu obavljaju javni bilježnici kao samostalni i neovisni nositelji službe koji imaju svojstvo osoba javnog povjerenja. Dakle, javni bilježnici su nepristrani savjetnici stranaka, nepristrani zapisivači njihove volje, koji stranke upoznaju o širini njihovih obveza koje ugovaraju, uređujući s jasnoćom njihove pogodbe, dajući im karakter autentičnog akta i snagu konačne presude, pritom pazeći na prevenciju nastanka sporova između sudionika javnobilježničkog postupka. S obzirom na visoko postavljene uvjete za imenovanje osobe javnim bilježnikom, stručnost javnih bilježnika, te njihovo permanentno stručno usavršavanje, pred javne bilježnike su postavljena visoka očekivanja u kvaliteti njihova rada i uspostavi pravne sigurnosti. Upravo zbog toga očekuje se da javni bilježnici ne griješe u svojem radu, a ako i pogriješe, da snose punu profesionalnu odgovornost za svoje pogreške. Javni bilježnici mogu profesionalno odgovarati na više različitih načina, od stegovne odgovornosti, preko prekršajne i kaznene, do građanskopravne odgovornosti. Zbog kratkoće forme, u ovom ćemo radu dati samo kratki prikaz profesionalne odgovornosti javnih bilježnika. Općenito gledano, pitanju odgovornosti profesionalaca u našoj pravnoj literaturi posvećeno je relativno malo sustavnijih istraživanja, što i ne začuđuje zbog kompleksnosti $i$ višeslojnosti problematike. 
Ključne riječi: osoba javnog povjerenja, savjetnik stranaka, profesionalna odgovornost, prevencija sporova, stegovna odgovornost, prekršajna odgovornost, kaznena odgovornost, građanskopravna odgovornost.

\section{Uvod}

Kako bismo u ovom radu mogli govoriti o profesionalnoj odgovornosti javnih bilježnika, najprije trebamo razlučiti što je uopće profesionalna odgovornost. Profesionalna odgovornost je odgovornost vršitelja određene djelatnosti koji tu djelatnost obavlja kao zanimanje, a kroz koju se vršitelja djelatnosti može pozvati na odgovornost prema strukovnim udruženjima, državi i/ili korisnicima njegovih usluga i trećim osobama zbog nepostupanja po propisima ili pravilima struke, te zbog neispunjenja, manjkavog ispunjenja ili zakašnjenja u ispunjenju preuzete obveze, odnosno u izvršavanju svoje profesionalne radnje. Ovakvo definiranje profesionalne odgovornosti je jako široko postavljeno i obuhvaća, odnosno izjednačava pojam profesionalne djelatnosti sa svakom djelatnošću koja predstavlja obavljanje bilo kojeg zanimanja. U ovom radu nije riječ o profesionalnim djelatnostima u najširem smislu, nego će biti riječi o profesionalnoj djelatnosti u užem smislu, koja se od općeg pojma razlikuje po nekim svojim specifičnostima i karakteristikama vezanim uz prirodu same djelatnosti i način njenog obavljanja. U ovom radu ćemo termin profesionalne djelatnosti koristiti u odnosu na profesionalne djelatnosti u užem smislu. ${ }^{1}$ Ove ćemo djelatnosti ponegdje nazivati $\mathrm{i}$ intelektualnim profesijama. Bitno je naglasiti da odgovornost profesionalaca ne predstavlja poseban, sui generis, oblik odgovornosti jer ne postoji neka neprofesionalna odgovornost. Zapravo se samo radi o kvaliteti, odnosno o kvalifikaciji odgovornosti. Ipak, u suvremenom građanskom pravu odgovornost vršitelja profesionalnih djelatnosti za štetu se shvaća kao specifičan oblik odgovornosti, iako ne postoje posebne zakonske odredbe koje bi na općoj razini uređivale odgovornost profesionalca za štetu. Iznimka je talijanski Građanski zakonik ${ }^{2}$ koji poseban odjeljak posvećuje upravo intelektualnim profesijama ${ }^{3}$, određujući da se pravila tog

\footnotetext{
${ }^{1}$ Vršiteljima profesionalnih djelatnosti u užem smislu se smatraju javni bilježnici, odvjetnici, arhitekti, ovlašteni graditelji, sve medicinske i njima srodne profesije, revizori, računovođe i sl., a u većini pravnih sustava se ovaj pojam proširuje i na pripadnike umjetničkih profesija. Ovdje ipak treba upozoriti da u pravnoj znanosti ne postoji općeprihvaćeni pojam profesionalnih (intelektualnih) djelatnosti, kao ni potpuna suglasnost o tome koje profesije spadaju u ovu kategoriju. Vrlo često se u teoriji pod pojmom "intelektualne profesije" smatraju javni bilježnici, odvjetnici, liječnici, arhitekti, porezni savjetnici, revizori i sl., dok se pod pojmom "slobodne profesije" smatraju slikari, pjevači, sportaši, glumci, književnici i sl.

${ }^{2}$ Codice civile, decreto 16 marzo 1942, n. 262 (I) (G.U. del 4. aprile 1942, 79 e 79 bis), dalje u tekstu: Codice civile.

${ }^{3}$ Libro quinto: Del lavoro; Titolo III: Del lavoro autonomo; Capo II: Delle professioni intelletualli (čl. 2229. - čl. 2238.).
} 
dijela zakona primjenjuju na ugovore u kojima je predmet činidbe jedne ugovorne strane intelektualno djelo. Naravno, posebni zakoni koji reguliraju pojedine profesionalne djelatnosti, te autonomni izvori prava (kao što su kodeksi profesionalne etike i sl.) sadrže neka pravila koja mogu poslužiti sudovima u rješavanju pojedinih aspekata problema odštetne odgovornosti profesionalca, posebno u utvrđivanju standarda dužne pažnje pripadnika profesije. U pravilu je riječ o vrlo općenitim odredbama koje nisu redigirane s ciljem da budu osnova za ustanovljavanje odštetne odgovornosti. U teoriji ne postoji neka konkretna definicija profesionalne djelatnosti te se kategorizacija određenih poslova kao profesionalnih djelatnosti, a samim time i primjena posebnih pravila o odgovornosti za štetu nositelja tih djelatnosti, može temeljiti samo na bogatoj sudskoj praksi. ${ }^{4}$ Profesionalne djelatnosti imaju nekoliko karakteristika koje ih diferenciraju od ostalih djelatnosti koje također zahtijevaju poznavanje određenih pravila struke. Te se karakteristike odnose na prirodu same djelatnosti i način obavljanja iste. Možda najvažnija karakteristika koja razlikuje profesionalne djelatnosti od ostalih djelatnosti je prevladavajući intelektualni karakter dugovane prestacije profesionalca. Naime, posao čije izvršenje se zahtijeva od profesionalca, vršitelja neke profesionalne djelatnosti, uvijek se sastoji od obavljanja neke umne djelatnosti, odnosno od obavljanja intelektualne radnje. Moguće je da se taj posao ne sastoji samo od obavljanja intelektualne radnje, ali je ista uvijek najvažniji dio zahtijevanog posla i predstavlja njen esencijalni dio. Ova karakteristika profesionalne djelatnosti se susreće u svim profesionalnim djelatnostima, bez iznimke, te je bitna za distinkciju profesionalnih djelatnosti u užem smislu od ostalih djelatnosti koje ljudi obavljaju profesionalno kao svoje zanimanje. ${ }^{5}$ Intelektualna komponenta rada je, naravno, prisutna i u ostalim djelatnostima, a ne samo u profesionalnim djelatnostima, ali je bitno da ista u profesionalnim djelatnostima predstavlja osnovni i prevladavajući element djelatnosti subjekta. Druga bitna karakteristika profesionalnih djelatnosti u užem smislu je strogo osobni karakter obveze profesionalca. Ova se karakteristika nadovezuje na prethodno obrađenu karakteristiku. Zbog njegovih znanja i intelektualnih sposobnosti ili vještina, traži se intelektualni rad konkretnog subjekta, te iz toga proizlazi i njegova osobna obveza poduzimanja tražene radnje. Radi se o tipičnim intuitu personae obligacijama u kojima su osobna svojstva izvršitelja bitan element odnosa sa strankom. Naravno da je, zbog prirode djelatnosti i fizičkih ograničenja, u mnogim slučajevima moguć prijenos (supstitucija) izvršenja obveze (cijele ili

\footnotetext{
${ }^{4}$ Vidi: Clerk \& Lindsell on Torts, $\left(18^{\text {th }}\right.$ edition, General editor: Antony M.Daugdale), Sweet \& Maxwell, London, 2000., str.441., prema: Petrić S., Problem pravne osnove profesionalne odgovornosti za štetu, Zbornik Pravnog fakulteta Sveučilišta u Rijeci, v. 25, br.1, 2004., str. 205.

${ }^{5}$ Loc.cit.
} 
njenog pojedinog dijela) na drugu osobu. Ovaj prijenos se uvijek vrši uz posebna ograničenja, na način da pravila struke određuju kada i na koga je moguća supstitucija, način prenošenja, odgovornost prenositelja i sl. Prijenos obveze se vrši, ali obveznik, u pravilu, nadzire rad izvršitelja i vrlo često za njega i odgovara. ${ }^{6}$ Ovo iz razloga jer je odnos na relaciji profesionalac - stranka zasnovan na povjerenju stranke u profesionalca i njegove sposobnosti. ${ }^{7}$ Iduća bitna karakteristika profesionalnih djelatnosti u užem smislu je povećana autonomija profesionalca. Ova se karakteristika također nadovezuje na intelektualni karakter obveze kod profesionalnih djelatnosti. Vršitelji slobodnih profesija, u pravilu, imaju diskrecijsku slobodu odlučivanja i izbora sredstava, načina i tehnika u izvršenju povjerenog posla. Ova sloboda u izvršenju je bitna odrednica profesionalnih djelatnosti i stoga u profesionalnim djelatnostima ne postoji klasičan odnos subordinacije, odnosno hijerarskijske podčinjenosti profesionalca volji onoga za koga obavlja traženi rad, odnosno radnje. Sve naprijed navedene i ukratko opisane karakteristike profesionalne djelatnosti zapravo proizlaze iz posebne prirode profesionalčeve prestacije.

U ovom radu ćemo obraditi najvažnija obilježja profesionalne odgovornosti javnih bilježnika kao tipičnih predstavnika profesionalnih djelatnosti (intelektualnih profesija). Profesionalna odgovornost javnih bilježnika ima cilj potaknuti javne bilježnike na veću pažnju pri obavljanju djelatnosti radi prevencije pogrešaka u radu. Obavljanjem svoje djelatnosti javni bilježnici (kao i svi ostali vršitelji profesionalnih djelatnosti) na sebe preuzimaju i određene profesionalne odgovornosti kojima se izlažu.

\section{Profesionalna odgovornost javnih bilježnika}

Da bi u jednom društveno-političkom uređenju postojala i funkcionirala vladavina prava, bitno je da nositelji pravosudnih djelatnosti, pa tako i javni bilježnici, imaju samostalnost u radu i neovisnost. Bitno je, također, da ti isti javni bilježnici kao jamstvo neovisnosti i nepristranosti imaju jasno uređena pravila o odgovornosti i razrješenju iz službe. Osnovni zakon koji regulira javno bilježništvo u Hrvatskoj je Zakon o javnom bilježništvu. ${ }^{8}$

\footnotetext{
${ }^{6}$ Npr. odvjetnik je obvezanik, ali izvršenje obveze može povjeriti svome zaposleniku (vježbenik i sl.). U ovom slučaju odvjetnik osobno ne izvršava obvezu, ali pazi kome će istu povjeriti, daje upute i nadgleda njeno izvršenje, te $u$ konačnici odgovara za isto.

${ }^{7}$ Tako i: Petrić S., Problem pravne..., op.cit., str. 207.

${ }^{8}$ Zakon o javnom bilježništvu Republike Hrvatske, (Narodne novine RH, br. 78/93., 29/94., 162/98., 16/07. i 75/09), dalje u tekstu: ZJB.
} 
Opće je pravilo da vršitelji određenih profesija snose odgovornost za obavljanje svoje profesije. ${ }^{9}$ To opće pravilo vrijedi i za javne bilježnike u obavljanju njihove profesionalne djelatnosti. Pitanje odgovornosti za štetu koju su nanijeli vršitelji određene profesije posebno je delikatno kod delegiranja nadležnosti s javnih tijela na privatne nositelje javnih službi, odnosno kada je vršenje određene profesije istovremeno i vršenje javne službe. U tom kontekstu nastali obveznopravni odnos nije samo privatna stvar subjekata tog odnosa; nije samo oštećena osoba zainteresirana da dobije naknadu za pretrpljenu štetu, već je to i interes države. Taj se interes ogleda, između ostalog, i u propisivanju obveznog osiguranja od odgovornosti za štetu prouzrokovanu vršenjem određene službe. ${ }^{10}$ Javni bilježnici za svoj rad odgovaraju cjelokupnom svojom imovinom kao dodatni poticaj da posvete veću pažnju u svojem svakodnevnom radu ${ }^{11}$. Na javne bilježnike se primjenjuje više različitih oblika odgovornosti. To su stegovna odgovornost, prekršajna odgovornost, kaznena odgovornost i građanskopravna odgovornost javnih bilježnika. Svaki od ovih oblika odgovornosti ima svoja posebna obilježja, specifičnosti i pravila. Međutim, postojanje više oblika odgovornosti ne znači da se moramo odlučiti samo za jedan oblik odgovornosti, tj. različiti oblici odgovornosti se međusobno ne isključuju, nego se u praksi mogu realizirati paralelno prema štetniku jer jedan drugog ne isključuju, a u pojedinim slučajevima su međusobno i komplementarni. O svakom od ovih oblika će biti više riječi u nastavku ovog rada.

\subsection{Stegovna odgovornost javnih bilježnika}

Stegovna odgovornost (još se naziva i disciplinska odgovornost) je vrsta odgovornosti javnih bilježnika koja je trenutno najviše i najdetaljnije razrađena u pozitivnom pravu. Stegovna odgovornost javnih bilježnika bi bila odgovornost javnog bilježnika za povredu službene dužnosti propisanu zakonom, pravilima službe i/ili običajem, za koju se u propisanom postupku

\footnotetext{
${ }^{9}$ Postoje iznimke u kojima pojedine vrste odgovornosti snosi netko drugi, a ne vršitelj djelatnosti. Tako primjerice građanskopravnu odgovornost za suce snosi država. Naravno da država ne može snositi sve vrste odgovornosti već samo građanskopravnu. Postoje i još mnogi drugi slični primjeri, osim sudačke profesije, u kojima građanskopravnu odgovornost snosi netko drugi, a ne sam vršitelj profesije.

${ }^{10}$ Tako: Povlakić M., Odgovornost notara za prouzrokovanu štetu u obavljanju notarske službe, Fondacija Centar za javno pravo, Sarajevo, 2009., str. 2.

${ }^{11}$ Tako: Plećaš J., Osiguranje javnih bilježnika od profesionalne odgovornosti, objavljeno na portalima notarius.hr i ius.info, dostupno na:

http://www.notarius.hr/Article/Content.aspx?SOPI=CLN20V01D2017B1061\&Doc=CLANCI -HR
} 
izriče zakonom i/ili pravilima službe određena stegovna kazna. Ovoj odgovornosti javni bilježnik podliježe u slučaju povrede službene dužnosti nastale vlastitom krivnjom. Ona ima cilj štititi ugled profesije od ponašanja koje je suprotno etičkim i profesionalnim standardima. Dakle, javni bilježnik disciplinski odgovara za povrede službene dužnosti koje učini svojom krivnjom, koja postoji u slučaju ponašanja koje je suprotno obvezama propisanim zakonskim i podzakonskim aktima. Kod ove vrste odgovornosti ne postoji mogućnost odgovornosti za drugoga. Disciplinska odgovornost postoji samo za dovršenu povredu ili propust, dakle za svršenu radnju koja predstavlja jednu od zakonom propisanih službenih dužnosti, ali ne i za pokušaj. ${ }^{12}$ Smatramo da je ovdje nužno istaknuti da je javni bilježnik disciplinski odgovoran samo dok obnaša službu. ${ }^{13}$ Ovlaštenje za utvrđivanje disciplinske odgovornosti i vođenje disciplinskog postupka je prvenstveno u nadležnosti javnobilježničke komore, a potom i u nadležnosti sudova. ${ }^{14}$ Stegovni prijestupi su ujedno i povrede službene dužnosti te se generalno mogu podijeliti na lake i teške povrede. Tako ZJB u čl. 145. povrede službene dužnosti dijeli na lake (neurednost) i teške (stegovni prijestup). Ovaj članak uvodno daje zajednički opis stegovnih djela, za koja kaže da su to djela kojima javni bilježnik svojim ponašanjem u obavljanju javnobilježničke službe ili privatnom životu vrijeđa čast i ugled javnobilježničke službe ili dovede u pitanje povjerenje u javnobilježničku službu, ako povrijedi službenu dužnost, osobito ako nepropisno obavlja službene radnje ili ako ih svojom krivnjom odugovlači. U nastavku tog članka se daje taksativni popis težih stegovnih djela te se navodi da javni bilježnik čini stegovni prijestup:

1) ako je postigao svoje postavljenje svjesno prikrivajući postojanje zakonskih zapreka za to,

2) ako povredi dužnost utvrđenu ovim Zakonom i time ozbiljno ugrozi povjerenje u svoju nepristranost i u isprave koje sastavlja, osobito ako poduzme službenu radnju u stvari u kojoj je po zakonu isključen, ili ako povredi dužnost čuvanja tajne,

3) ako se ne pridržava zakonskih odredbi o kojima ovisi valjanost javnobilježničke isprave,

4) ako potvrdi da se dogodila činjenica koja se nije dogodila u njegovoj nazočnosti,

\footnotetext{
${ }^{12}$ Tako: Povlakić M. et al., Komentar zakona o notarima u Bosni i Hercegovini, Njemačka organizacija za tehničku suradnju (GTZ) GmbH, Sarajevo, 2009., str. 293.

${ }^{13}$ Vidi rješenje Vrhovnog suda Republike Hrvatske broj I Kž Disc. 1/04-4, od 14.11.2005. godine, dostupno u: Borčić J., Skorup V., Javnobilježničke isprave i javni bilježnici kroz sudsku praksu, Javni bilježnik 27-poseban broj, 2008., str. 81.-82.

${ }^{14}$ Čl. 150. st. 1. i 2. ZJB
} 
5) ako protivno javnobilježničkoj tarifi zaračunava i traži veću nagradu, ili ako kao sudski povjerenik vrši pritisak na stranke da ga postave za svog zastupnika,

6) ako uz obećanje da će sniziti nagradu preko posrednika ili na drugi nedoličan način traži stranke,

7) ako zastupa stranku ili sastavlja isprave u slučajevima u kojima mu je to zakonom zabranjeno,

8) ako grubo povrijedi dužno poštivanje prema sudovima i nadzornim tijelima,

9) ako se ne pokorava pravomoćnim odlukama sudova i nadzornih tijela.

10) ako neuredno vodi knjige, osobito ako ostavlja prazne rubrike, ili nemarno upravlja svojim uredom,

11) ako pomaže nadripisare potpisivanjem njihovih podnesaka, davanjem savjeta i mišljena ili prikrivanjem njihove djelatnosti,

12) ako sastavlja, protivno zakonu, javnobilježničke isprave na jeziku koji nije službeni,

13) ako na javnoj dražbi ili tijekom kojeg drugog postupka koji vodi kao javni bilježnik, ili kao povjerenik suda, ili kao zastupnik stranaka, kupi za sebe ili za svoje srodnike stvar koja se prodaje ili kupi tražbine, nasljedna ili druga prava,

14) ako obavlja za plaću državnu ili koju drugu stalnu javnu ili privatnu službu, ako se bavi trgovinom ili posredničkim poslovima, ili zanimanjem koje nije u skladu s ugledom, čašću ili nezavisnošću javnog bilježnika, ako sklapa poslove pod svojim imenom za druge ili pod tuđim imenom za sebe ili ako je sudionik u poslovima u kojima poduzima službene radnje kao javni bilježnik ili sudski povjerenik, ako novac koji mu je povjeren na čuvanje, uloži na svoje ime protivno odredbama ovoga Zakona, ako preuzme obvezu jamstva ili odgovornosti u poslovima koji se sklapaju uz njegovo sudjelovanje u svojstvu javnog bilježnika,

15) ako prigodom prijema javnobilježničkih prisjednika ili vježbenika povredi pravila o izboru javnobilježničkih prisjednika i vježbenika,

16) ako za vrijeme za koje mu je privremeno oduzeto pravo na obavljanje službe obavlja javnobilježničke poslove ili na drugi način izigrava tu kaznu. 
U narednim člancima se navode kazne za lakša stegovna djela (neurednost) i teža stegovna djela (prijestup). Tako su kazne za lakša stegovna djela (neurednost):

1) pismena opomena,

2) novčana kazna do visine jedne osnovne mjesečne plaće suca prvostupanjskog suda, plaćanje koje se može odrediti u najviše pet jednakih mjesečnih obroka.

Kazne za teža stegovna djela (prijestup) su:

1) pismeni ukor,

2) novčana kazna do visine tri osnovne mjesečne plaće suca prvostupanjskog suda, plaćanje koje se može odrediti u najviše šest jednakih mjesečnih obroka,

3) privremeno oduzimanje prava na obavljanje službe u trajanju do godinu dana,

4) oduzimanje prava na obavljanje službe.

Ovdje moramo pohvaliti rješenje hrvatskog zakonodavca, kojim su stegovna djela podijeljena na lakša i teža, čime se uklanja opasnost teških kazni za djela koja po svojoj naravi nisu takva da bi se najteže kazne za njih trebale izricati. U nekim zemljama postoje dosta lošija rješenja. Tako, primjerice, u rješenjima predviđenima u notarskim propisima FBiH, R. Srpske i Brčko distrikta nije utvrđeno koje povrede predstavljaju lakše, a koje teže povrede službene dužnosti, što nije učinjeno ni podzakonskim aktima. Iz ovoga proizlazi velika opasnost za javne bilježnike (notare) jer im se za svako stegovno djelo može izreći bilo koja kazna, od onih najblažih pa sve do razrješenja od obavljanja službe. ${ }^{15}$ Naravno da je u praksi mala vjerojatnost da će netko biti razriješen dužnosti za neku najblažu povredu službene dužnosti, ali bi bilo dobro, radi povećanja pravne sigurnosti, otkloniti ove nedostatke i propisati koje povrede su teže, a koje su lakše, te shodno tome, prilagoditi i kazne za iste. Ovdje ćemo nešto reći i o zastari stegovnih djela. Smatramo da je zastara stegovnih djela u RH iznimno loše uređena, usudili bi se reći i da je protuustavna jer javne bilježnike stavlja u neravnopravan položaj u odnosu na druge srodne profesije. Naime, kako je člankom 149. st. 1. ZJB, kod zastare gonjenja za stegovnu neurednost i za stegovni prijestup javnog bilježnika, odredeno da je zastarni rok za stegovne neurednosti dvije godine, a za stegovne prijestupe pet godina, a kako u članku 155. ZJB, kao ni u drugim člancima ZJB nema propisa o zastari ovrhe stegovnih odluka, to javne bilježnike dovodi u

\footnotetext{
${ }^{15}$ Slično: Oruč E., Odgovornost notara u pravnom sistemu Bosne i Hercegovine - de lege lata i de lege ferenda, Revija za pravo i ekonomiju, 2012., str. 40.- 41.
} 
nejednakost koja nije u skladu s Ustavom $\mathrm{RH},{ }^{16}$ a u prvom redu s ustavnim načelom jednakosti sadržanim u odredbama čl. 3. i 14. Ustava. Ovdje se nejednakost očituje dvojako: u odnosu javnih bilježnika prema drugim pravosudnim djelatnicima (sucima i zamjenicima državnih odvjetnika), a i prema državnim činovnicima koji podliježu stegovnom progonu prema odredenoj regulaciji u svezi njihove stegovne odgovornosti. I za suce i za zamjenike državnih odvjetnika je propisano da se stegovni postupak ne smije pokrenuti nakon jedne godine od saznanja za počinjeno stegovno djelo i počinitelja, odnosno tri godine od počinjenja stegovnog djela, s time da se stegovna djela ovih osoba ne dijele na neurednosti i stegovne prijestupe kao kod javnih bilježnika, dok ovrha stegovne kazne i za jedne i druge zastarijeva za godinu dana od njene pravomoćnosti. Usporedbe radi, navodimo kako zastara za pokretanje postupka zbog teške povrede službene dužnosti i za državne službenike zastarijeva u roku od godine dana od dana saznanja za počinjenu povredu i počinitelja, a najkasnije u roku od tri godine od dana kada je povreda počinjena, dok ovrha kazne za laku povredu službene dužnosti od državnog službenika zastarijeva u roku od jedne godine, a za tešku povredu službene dužnosti u roku od dvije godine od konačnosti rješenja kojim je kazna izrečena.

Svi zakoni koji uređuju postupanja službenih osoba, gledajući sa stajališta da uređuju istu pravnu materiju, odnosno stegovnu odgovornost određenih počinitelja stegovnih djela kao posebnih vrsti kažnjivih radnji, koje putem određenih tijela nadzire država, bez obzira iz koje službe dolazili (iz reda sudaca, zamjenika državnih odvjetnika, državnih službenika i namještenika, pripadnika oružanih snaga ili, pak, javnih bilježnika), u suštini je jedan zakon koji je samo formalno raspoređen u zasebne cjeline. Zbog toga, po našem mišljenju, počinitelji ovih stegovnih djela zakonom ne smiju biti stavljeni u nejednak položaj, tako da rok zastare za progon jednih, zbog počinjenja istog stegovnog djela, može biti kraći, a za progon drugih duži. ${ }^{17,18}$ Za usporedbu, u crnogorskom pravu, člankom 119. tamošnjeg zakona o notarima, ${ }^{19}$ propisano je da disciplinski tužilac podnosi zahtjev za pokretanje disciplinskog postupka najkasnije u roku od 30 dana od dana saznanja, odnosno u roku od tri mjeseca od dana kada je povreda učinjena, te da će neblagovremeni zahtjev za pokretanje disciplinskog postupka

\footnotetext{
${ }^{16}$ Ustav Republike Hrvatske, (Narodne Novine RH, br. 56/90, 135/97, 8/98, 113/00, 124/00, 28/01, 41/01, 55/01, 76/10, 85/10, 05/14.).

${ }^{17}$ Prema stajalištu drugostupanjskog disciplinskog vijeća Vrhovnog suda Republike Hrvatske, u odluci I Kž Disc 1/06, KŽ-DO-638/06, od 15.5.2006. protiv javnog bilježnika zastara stegovnog progona nastupa tek po proteku roka od 10 (deset) godina od počinjenja stegovnog djela, što je dva do tri puta duži rok od zastarnih rokova bilo kojih drugih službenih osoba spomenutih u ovom dijelu teksta.

${ }^{18}$ Tako i: Žanko P., Izdvojeno mišljenje člana javnobilježničkog disciplinskog vijeća u predmetu Vrhovnog Suda RH I Kž Disc 1/06, KŽ-DO-638/06.

${ }^{19}$ Zakon o notarima Crne gore, Službeni list RCG, br. 68/2005 i 49/2008, u daljnjem tekstu: ZNot CG.
} 
disciplinska komisija odbaciti. Prema istom članku, postupak za utvrđivanje disciplinske odgovornosti notara mora se okončati u roku od tri mjeseca od dana podnošenja zahtjeva. Slično crnogorskom rješenju je i u BiH. Tako npr. Pravilnik o disciplinskoj odgovornosti notara notarske komore Republike Srpske ${ }^{20}$ propisuje, u čl. 31., da se pokretanje disciplinskog postupka protiv notara ne može poduzeti kada protekne šest mjeseci od izvršene povrede urednog obavljanja notarske djelatnosti, a ako učinjena povreda urednog obavljanja notarske djelatnosti ima bitna obilježja kaznenog djela, zastara pokretanja i vođenja disciplinskog postupka nastupa kada po zakonu nastupa zastara kaznenog gonjenja za to kazneno djelo. Zastara disciplinskog gonjenja nastupa u svakom slučaju kada protekne dvostruko vrijeme iz stavka 1. ovog članka, tj. ukupno jedna godina. Slične rokove, dosta kraće od ovih koji su propisani u ZJB, određuje i Savezni disciplinski zakon Njemačke, ${ }^{21}$ a na koji upućuje $\S 96$. i druge Savezne uredbe o notarima Njemačke. ${ }^{22}$ Zbog naprijed navedenoga, smatramo da bi hrvatski zakonodavac morao intervenirati u ove propise i što prije ih uskladiti, prije svega $\mathrm{s}$ Ustavom RH, a potom i s tekovinama modernih europskih notarijata latinskog tipa.

\subsection{Prekršajna odgovornost javnih bilježnika}

Javni bilježnici su osobe s mnogim javnim ovlaštenjima, ali i obvezama. Vrlo često je za nepostupanje po propisanim obvezama, javnim bilježnicima zapriječena prekršajna kazna, i to novčana kazna, u pravilu. Obično su prekršaji određeni nekim drugim propisima, a ne propisima kojima se regulira javnobilježnička služba. Najčešće su to propisi iz poreznih, te obiteljskopravnih područja. Tako npr. Zakon o porezu na promet nekretnina ${ }^{23}$ Republike Hrvatske u članku 18. određuje da je javni bilježnik po ovjeri potpisa na ispravama o prodaji ili drugom načinu otuđenja nekretnine ili po sastavljanju javnobilježničkog akta, a najkasnije u roku od 30 dana, obvezan jedan primjerak isprave, kao i svake druge isprave na osnovi koje dolazi do prometa nekretnine (ugovor o ortaštvu, ugovor o osnivanju prava građenja i sl.), uz

\footnotetext{
${ }^{20}$ Pravilnik o disciplinskoj odgovornosti notara notarske komore Republike Srpske, Službeni glasnik Republike Srpske broj 14/15.

${ }^{21}$ Savezni disciplinski zakon Njemačke (Bundesdisziplinargesetz), Bundesgesetzblatt IS 1510/2001, IS 2554/2011, dostupno na:

http://www.europam.eu/data/mechanisms/COI/COI\%20Laws/Germany/Germany_Disciplinary\%20Law_2001\% 20amended\%202015.pdf.

${ }^{22}$ Savezna uredba o notarima Njemačke (Bundesnotarordnung) iz 1961. godine. To je osnovni propis kojim se uređuje notarijat u Njemačkoj.

${ }^{23}$ Zakon o porezu na promet nekretnina, Narodne novine br. 115/16, u daljnjem tekstu: Zakon o porezu na promet nekretnina RH.
} 
podatak o osobnom identifikacijskom broju sudionika postupka, dostaviti ispostavi Porezne uprave na području kojem se nekretnina nalazi, elektroničkim putem. Istodobno, članak 31. Zakona o porezu na promet nekretnina RH propisuje da će se novčanom kaznom od 5.000,00 do 100.000,00 kuna kazniti za prekršaj javni bilježnik ako na propisani način nadležnoj ispostavi Porezne uprave ne dostavi ispravu s ovjerovljenim potpisom, odnosno odluku kojom se mijenja vlasništvo na nekretnini, kao i svaku drugu ispravu na osnovi koje dolazi do prometa nekretnine (ugovor o ortaštvu, ugovor o osnivanju prava građenja i sl.), uz podatak o osobnom identifikacijskom broju sudionika postupka, sukladno članku 18. ovoga zakona. Ovaj propis je u izravnoj suprotnosti s člankom 77. st. 4. ZJB koji, između ostaloga, kaže da pri ovjeri potpisa javni bilježnik nije odgovoran za sadržaj pismena niti je dužan ispitivati jesu li sudionici ovlašteni na dotični posao, pa čak i da javni bilježnik može ovjeriti potpis i na ispravi koja je napisana na jeziku koji nije službeni (dakle, javni bilježnik ne mora biti sposoban niti razumjeti ispravu). Postavlja se pitanje kako će javni bilježnik ispuniti obvezu iz članka 18. Zakona o porezu na promet nekretnina $\mathrm{RH}$, te dostaviti svaku ispravu na osnovi koje dolazi do prometa nekretnine, uz podatak o osobnom identifikacijskom broju sudionika postupka, ako stranke koje su možebitno same pisale predmetnu ispravu nisu u samoj ispravi navele podatke o osobnom identifikacijskom broju (OIB) sudionika postupka. Prema Zakonu o zemljišnim knjigama, ${ }^{24}$ čak nije propisana niti obveza da svi sudionici u ugovoru ovjere svoje potpise, nego samo oni čije se vlasništvo prenosi, ograničava i sl., iako je porezni obveznik u pravilu stjecatelj nekretnine. Javni bilježnik nadležnoj Poreznoj upravi mora dostaviti podatak o OIB-u, a on sam nije sastavljao ispravu, niti raspolaže potrebnim podacima stranaka. Nadalje, moguća je situacija u kojoj stranac stječe nekretninu u Republici Hrvatskoj, s obzirom da je RH članica Europske unije, te državljani EU-a mogu nesmetano stjecati nekretnine u RH, uz neka manja ograničenja. Stranac ni nema svoj OIB (dok mu ga Porezna uprava ne dodijeli), ali je došao u ured javnog bilježnika zajedno s prodavateljem nekretnine te su sami unaprijed sastavili ispravu o kupoprodaji nekretnine, a od javnog bilježnika traže samo ovjeru potpisa. Tu nastaje problem za javnog bilježnika. Zakon o porezu na promet nekretnina $\mathrm{RH}$ je propisao visoke kazne za javne bilježnike ako ne dostave podatak o osobnom identifikacijskom broju sudionika postupka, pa zbog toga javni bilježnik ne bi trebao ovjeriti potpise na toj ispravi jer bilježnik riskira visoku novčanu kaznu. S druge strane, za obavljanje određenih poslova je propisana isključiva nadležnost javnih bilježnika, tj. javni bilježnik je jedina osoba koja je ovlaštena obaviti ovjeru

\footnotetext{
${ }^{24}$ Zakon o zemljišnim knjigama, Narodne novine br. 91/96, 68/98, 137/99, 114/01, 100/04, 107/07, 152/08, 126/10, 55/13, 60/13, u daljnjem tekstu: ZZK RH.
} 
potpisa, pa se stranka mora obratiti javnom bilježniku za obavljanje te radnje. Javni bilježnik kao nositelj javne službe ne može slobodno odlučivati o tome hoće li poduzeti službenu radnju koja mu je povjerena ili ne, nego je, u pravilu, dužan obaviti zatraženu službenu radnju ovjere potpisa, te istu ne smije odbiti obaviti, osim u zakonom predviđenim slučajevima. ${ }^{25}$ Ova situacija i konflikt ZJB i Zakona o porezu na promet nekretnina RH koegzistiraju i dovode javne bilježnike u svakodnevne probleme u radu. Unatoč brojnim i učestalim problemima, ovaj problem je i dalje nerješiv sve dok se u potpunosti ne promjeni sustav prometa nekretnina $u$ Hrvatskoj. Za razliku od Hrvatske, Bosna i Hercegovina nema ovakvih problema jer je u BiH javni bilježnik isključivo nadležan za sastav isprava o prijenosu vlasništva (i drugih stvarnih prava) na nekretninama, pa on time sam odgovara za sadržaj isprava o prijenosu vlasništva i tada je potpuno opravdano prekršajno ga kazniti ako u ispravu ne unese sve obvezne podatke. U Hrvatskoj su javnim bilježnicima ruke vezane i samo je pitanje vremena kada će doći do kolapsa i urušavanja sustava oporezivanja i poreznih prekršaja. Ovdje se radi o situaciji kada javni bilježnik mora prekršajno odgovarati za nečiju tuđu radnju, a ne za svoju. Kada bi javni bilježnici bili isključivo nadležni za sastav isprava o prometu nekretnina, to bi iznimno doprinijelo povećanju pravne sigurnosti, smanjenju zemljišnoknjižnih predmeta, ukidanju nadripisarstva, povećanju fiskalnih prinosa i sl., ali u ovom radu nećemo veću pažnju pridavati sustavu prometa nekretnina u Republici Hrvatskoj.

Osim prekršaja i problema koji proizlaze iz činjenice da javni bilježnici sami ne sastavljaju sve isprave, prekršaji i problemi mogu proizaći i iz isprava koje sastavi sam bilježnik, a da to opet bude bez njegove krivnje. Javni bilježnici, kao povjerenici sudova, vode ostavinske postupke, te u istima imaju prava i obveze sudaca. Zakonom o nasljeđivanju Republike Hrvatske ${ }^{26}$ je propisan obvezni sadržaj rješenja o nasljeđivanju. Između ostaloga, propisana je obveza da se u rješenje o nasljeđivanju unese podatak o osobnom identifikacijskom broju (OIB) ostavitelja, svih nasljednika, te svih zapisovnika ako ih ima, a Zakon o porezu na promet nekretnina RH obvezuje javne bilježnike da dostave svaku ispravu temeljem koje dolazi do prijenosa vlasništva na nekretninama, uključujući i rješenja o nasljeđivanju. Dakle, javni bilježnik vodi ostavinski postupak i sam sastavlja, nakon provedenog postupka, rješenje o nasljeđivanju sa sadržajem koji je propisan u ZN RH. Zamislimo hipotetsku situaciju koja je relativno česta u svakodnevnom radu i životu. Ostavitelj, kojemu je supruga ranije preminula te više nije bio u

\footnotetext{
${ }^{25}$ Tako: Prančić V., O dužnosti poduzimanja i uskrati službene radnje javnog bilježnika, Zbornik Pravnog fakulteta u Zagrebu, vol. 58 (4), 2008., str. 1003.

${ }^{26}$ Zakon o nasljeđivanju, Narodne novine br. 48/03, 163/03, 35/05, 127/13, 33/15, u daljnjem tekstu: ZN RH.
} 
braku, imao je petoro djece, a umro je bez oporuke. Dakle, on ima pet nasljednika koji nasljeđuju na jednake dijelove, tj. svaki za 1/5 dijela prava vlasništva. Svi uredno primaju pozive na ostavinsku raspravu, a na raspravi se pojavi njih četvero, dok peti nasljednik ne dolazi. Bilježnik bi, po pravilima nasljednog prava, trebao donijeti rješenje, svakome od nasljednika dodijeliti njegovu petinu ostavine te poslati otpravak rješenja svim nasljednicima. Ako svi uredno prime i ne ulože prigovor/žalbu, po proteku propisanih rokova, rješenje postaje pravomoćno i nasljednici mogu raspolagati nasljeđenim dijelovima imovine. U našoj hipotetskoj situaciji će od imovine biti kuća, dva automobila i novčana sredstva na štednom računu. Zbog neusklađenosti propisa, javni bilježnik ne smije uopće donijeti ovo rješenje pa samim time ni otpravak dostaviti strankama, te stranke uopće ne mogu dobiti pravomoćno rješenje o nasljeđivanju, pa posljedično ne mogu ni raspolagati ni nasljeđenim dijelovima imovine jer je propisana kazna javnom bilježniku do 100.000,00 kuna ako donese rješenje o nasljeđivanju bez OIB-a svih nasljednika. U našoj hipotetskoj situaciji peti nasljednik se nije pojavio na raspravi kod javnog bilježnika, niti je poslao nasljedničku izjavu. On nije u dobrim odnosima s ostalim sunasljednicima, pa namjerno prima poštu, ali ne želi dostaviti svoj podatak o OIB-u niti se ikako očitovati jer ga na to zakon čak niti ne obvezuje. Da sažmemo ovaj hipotetski slučaj. Javni bilježnik ne smije/ne želi donijeti rješenje bez OIB-a svih nasljednika, te zbog inata jednog od nasljednika svi ostali nemaju rješenje o nasljeđivanju i ne mogu raspolagati nasljeđenom imovinom. Ovo se s teorijske strane malo ublažava činjenicom da je rješenje o nasljeđivanju samo deklaratorne prirode, da su nasljednici postali vlasnici nasljeđene imovine već trenutkom otvaranja nasljedstva (smrti ostavitelja), ali u praktičnom smislu i u svakodnevnom životu ovo prouzrokuje velike probleme nasljednicima jer se isti ne mogu uknjižiti na nekretnine, ne mogu raspolagati novčanim sredstvima na računima u bankama, ne mogu registrirati vozila na svoje ime i sl.

Naprijed opisani problemi zbog propisanih prekršaja za javne bilježnike su svakim danom sve veći i nužna je hitna intervencija u navedene propise, te iste de lege ferenda, uskladiti.

Pored naprijed navedenih prekršaja koje javni bilježnik može počiniti samo kao javni bilježnik, postoje i prekršaji koje on može počiniti u okviru obavljanja svoje službe, ali te iste prekršaje mogu počiniti i druge osobe, koje nisu javni bilježnici. Tako npr. javni bilježnik može počiniti prekršaje iz propisa o fiskalizaciji, o porezu na dodanu vijednost, razne prekršaje iz propisa o računovodstvu i financijama, prekršaje iz propisa o radu kojima se krše radnička prava, prekršaje iz propisa o sigurnosti i zaštiti na radu i sl., ali ti prekršaji nisu važni za ovaj rad jer oni nisu povezani s javnim bilježnikom kao nositeljem javne službe, nego samo s javnim 
bilježnikom kao s osobom koja nastupa u gospodarskom prometu te ćemo stoga iste prekršaje u ovom radu zanemariti. Detaljnije analize slučajeva prekršajne odgovornosti prelaze okvire ovoga rada, ali već i sam njihov pregled pokazuje kako se radi o vrlo kompleksnoj problematici koja zaslužuje biti predmetom zasebnog znanstveno-istraživačkog rada.

\subsection{Kaznena odgovornost javnih bilježnika}

Javni bilježnici su osobe koje obavljaju službu s javnim ovlastima te time ulaze u krug potencijalnih počinitelja kaznenih djela koja svrstavamo u kategoriju tzv. delicta propria, tj. posebnih kaznenih djela koja mogu počiniti samo osobe s određenim svojstvom. Ova djela, dakle, mogu počiniti samo osobe s posebnim položajem i svojstvom. Naravno da javni bilježnici mogu počiniti i druga kaznena djela, pored ovih tzv. delicta propria, ali za ta će kaznena djela odgovarati po općim pravilima kaznenog postupka kao i svi ostali eventualni počinitelji kaznenih djela. U ovom radu zadržat ćemo se na obrađivanju kaznene odgovornosti javnih bilježnika za djela učinjena u obavljanju javnobilježničke službe, odnosno u svezi s obavljanjem iste. Bitno je naglasiti da kaznena odgovornost, u pravilu, ${ }^{27}$ nije uvjet građanske odgovornosti.

Prema hrvatskim propisima, javni bilježnici bi mogli odgovarati za kaznena djela iz Glave dvadeset osme (XXVIII.), Kaznenog zakona, čl. 291.-300., ${ }^{28}$ a to su kaznena djela protiv službene dužnosti. KZ RH ne sadrži posebnu odredbu koja bi u sebi sadržavala kazneno djelo koje bi mogao počiniti samo javni bilježnik, već oni odgovaraju za počinjena kaznena djela kao

\footnotetext{
27 “Po važećem hrvatskom pravu odgovornosti za štetu utvrđenje (postojanje) kaznenog djela kao pretpostavke odgovornosti predviđeno je samo u jednom slučaju (st. 4. čl. 1089. - kada je stvar uništena ili oštećeno kaznenim djelom učinjenim namjerno, sud može odrediti visinu naknade prema vrijednostima koju je stvar imalo za oštećenika). Radi se o tzv. afekcijskoj vrijednosti (praetium affectionis); to je posebna subjektivna vrijednost stvari koja nije procjenjiva objektivnim mjerilima (Klarić-Vedriš, op. cit., str. 89.). U praksi odštetnog prava „vječno“ je sporno pitanje može li se u građanskoj parnici pitanje postojanja kaznenog djela rješavati kao prethodno pitanje (posebno, npr. kada je pri izazivanju kaznenog djela njegov počinitelj umro); nama se čini da to ne bi smjelo biti sporno jer je u naravi opće kompetencije redovnog suda da sam rješava prethodna (prejudicijelna) pitanja (arg. iz čl. 12. ZPP, tako i Triva-Dika: Građansko parnično procesno pravo, Zagreb, 2004., str. 96.-102.). Pravilo rezultira iz potrebe „uzajamnog povjerenja u pravilnost odluke nadležnog tijela“. Postoje i sustavi gdje propisi predviđaju odštetnu odgovornost samo pod točno određenim pretpostavkama, a ne općim, apstraktno postavljenim uvjetima (tako, npr. Italija odgovornost za naknadu neimovinske štete predviđa samo za slučaj kaznenog djela - čl. 2059. Codice civile); sudska praksa je od toga „pobjegla“ konstrukcijom novih pojmova - „moralna šteta“, „biološka šteta“, „egzistencijalna šteta“. Vodinelić (op. cit., str. 491.) posebno ukazuje na razlike (ali i sličnosti) u europskim sustavima ugovorne i izvanugovorne odgovornosti za štetu." Prema: Radolović A., Načelo zabrane prouzročenja štete kao (moguće) jamstvo stvarne (realne) naknade štete, Zbornik Pravnog fakulteta Sveučilišta u Rijeci, v. 34, br. 1, 2013., str. 309.

${ }^{28}$ Kazneni zakon, Narodne novine br. 125/11, 144/12, 56/15, 61/15, u daljnjem tekstu: KZ RH.
} 
i sve druge osobe, odnosno za djela počinjena u službi odgovaraju kao i druge službene osobe budući da je člankom 87. st. 3. KZ RH određeno da javni bilježnik ima svojstvo službene osobe. ${ }^{29}$ Značajka kaznenih djela protiv službene dužnosti izražava se u okolnosti što službenik obavljanjem svojih dužnosti povrjeđuje upravo tu službenu dužnost koja mu nameće obvezu postupanja u skladu s pravnim propisima. "Specifičnost takvih djela izražava se stoga, mogli bismo reći, u tri elementa. Prvo, to su kaznena djela koja čine službene osobe, drugo, to su djela koja se čine povredom posebnih dužnosti i ovlasti koje imaju službene osobe prema svom svojstvu, i treće, to su djela koja se po posebnim odredbama Kaznenog zakona propisuju kao kaznena djela za koja se predviđaju kaznene sankcije." ${ }^{30}$

U ZJB postoje posebne odredbe o pretrazi ureda i pritvoru javnih bilježnika. Tako članak 40. ZJB kaže: pretraga ureda i oduzimanje isprava koje su povjerene na čuvanje javnom bilježniku, novca i predmeta od vrijednosti koje je javni bilježnik preuzeo radi predaje trećim osobama te javnobilježničkih spisa i knjiga, dopušteno je samo glede isprava, predmeta i knjiga koje su izričito navedene u odluci o pretrazi donesenoj u kaznenom postupku protiv javnog bilježnika. Pri pretrazi ureda mora biti nazočan predstavnik Komore. Javni bilježnik ne smije biti pritvoren u kaznenom postupku koji je protiv njega pokrenut zbog sumnje da je počinio kazneno djelo u obavljanju javnobilježničke službe, bez dopuštenja vijeća trojice sudaca suda drugog stupnja na području kojega se nalazi sud koji vodi postupak. O određivanju pritvora sud je dužan obavijestiti Komoru. Iako je tema ovog rada profesionalna odgovornost javnih bilježnika u Republici Hrvatskoj, smatramo da je važno ukazati na pojedine odredbe o kaznenoj odgovnosti javnih bilježnika u BiH, s obzirom da su tamošnjim pravom neke stvari znatno bolje regulirane, te bismo pojedina rješenja mogli jednostavno preuzeti u hrvatski pravni sustav. Tako su u BiH, po našem mišljenju, pravilnije i pravednije odredbe o privremenom udaljenju iz službe, kojima je propisano da će javni bilježnik biti privremeno udaljen iz službe ako je, između ostaloga, protiv njega podignuta optužnica ili određen pritvor zbog kaznenog djela počinjenog $\mathrm{s}$ umišljajem, ili ako izdržava kaznu zatvora do šest mjeseci. Za razliku od ovog rješenja iz BiH, u hrvatskom pravu je dosta lošija odredba o privremenom udaljenju iz službe koja kaže da će

\footnotetext{
${ }^{29}$ Čl. 87. st. 3. KZ RH kaže da je službena osoba državni dužnosnik ili službenik, dužnosnik ili službenik u jedinici lokalne i područne (regionalne) samouprave, nositelj pravosudne dužnosti, sudac porotnik, član Državnog sudbenog vijeća ili Državnoodvjetničkog vijeća, arbitar i javni bilježnik. Službenom osobom smatra se i osoba koja u Europskoj uniji, stranoj državi, međunarodnoj organizaciji koje je Republika Hrvatska član, međunarodnom sudu ili arbitraži čiju sudbenost Republika Hrvatska prihvaća, obavlja dužnosti povjerene osobama iz prethodne rečenice.

${ }^{30}$ Borković, I., Službeničko pravo, Informator, Zagreb, 1999., str. 153., prema: Galiot M., Čović S., Juras D., Kaznena i stegovna (disciplinska) odgovornost sudaca - Zbornik Pravnog fakulteta Sveučilišta u Rijeci, v. 34, br. 2, 2013., str. 863.
} 
se privremeno udaljenje uvijek odrediti ako je, između ostalog, javni bilježnik stavljen pod istragu zbog kaznenog djela učinjenog iz koristoljublja ili kojeg drugog nečasnog kaznenog djela. Dakle, javni bilježnik se razrješuje dužnosti, doduše privremeno, samim činom pokretanja istrage. BiH je ovo ipak podigla na višu razinu i traži da je protiv javnog bilježnika barem podignuta optužnica, što je dosta pravednije rješenje. Naime, ako bilo koja osoba podnese kaznenu prijavu protiv javnog bilježnika, makar ona bila i lažna i potpuno neosnovana, ako je za djelo čiji se počinitelji gone po službenoj dužnosti, istraga mora biti pokrenuta, također, po službenoj dužnosti. Ovo predstavlja veliku opasnost za pravnu sigurnost jer tada javni bilježnik biva udaljen iz službe do okončanja kaznenog postupka, a koji postupak, zbog sporosti pravosudnih tijela i preopterećenosti sudova, može biti okončan tek nakon nekoliko godina. Za vrijeme privremenog udaljenja iz službe, u tom javnobilježničkom uredu se imenuje vršitelj dužnosti javnog bilježnika, a koji javnobilježničku službu obavlja u svoje ime i, što je važnije za ovu situaciju, za svoj račun. Dakle, privremeno udaljeni javni bilježnik ostaje bez izvora prihoda, a zbog prirode službe i činjenice da nije trajno razriješen, ne smije se zaposliti niti obavljati neku drugu službu, zbog nespojivosti s javnim bilježništvom. Ovime se javnog bilježnika može dovesti „,na prosjački štap“, a država (i eventualno prijavitelj kaznenog djela) se izlaže odgovornosti za naknadu štete, izgubljenu dobit i sl. Posebno napominjemo da se u ovom slučaju radi i o grubom kršenju presumpcije nevinosti i prava na rad, no očito je da se radi o vrlo kompleksnoj problematici koju nije moguće u cjelosti obraditi u ovom radu.

Kaznena odgovornost javnih bilježnika je specifična u još jednom pogledu. Naime, javni bilježnici mogu odgovarati kao javni bilježnici, ali i kao suci, s obzirom da javnim bilježnicima sudovi povjeravaju vršenje pojedinih radnji koje izvorno svrstavamo u sudske, te u vršenju tih radnji javni bilježnici imaju sva prava i ovlasti sudaca. U nekim zakonodavstvima (npr. Njemačka) postoje posebna kaznena djela „kršenje zakona suca“. Ovakvo kazneno djelo je poznavao i hrvatski kazneni sustav do 1997. godine, ali ga od tada nema u kaznenom zakonu, nego je kazneno djelo koje počini sudac ,pokriveno“ kaznenim djelima protiv službene dužnosti, kao što je to naprijed navedeno. Iako se, dakle, zakonom ne pravi razlika između sudaca i ostalih službenih osoba, važno je naglasiti da je Vrhovni sud RH zauzeo stajalište i razvio praksu da se činjenica da zlouporabu položaja i ovlasti čini sudac uzima kao otegotna okolnost. Dakle, iz toga proizlazi da nije svejedno je li javni bilježnik djelo počinio kao javni bilježnik ili u ulozi suca kad mu je ista povjerena.

Mnogi vršitelji javnih službi imaju određene vrste imuniteta u obavljanju svoje službe. Postoji tzv. materijalni imunitet (npr. sudac ne može odgovarati za svoj stav o određenom pravnom 
pitanju i njegovoj primjeni u rješavanju konkretnog spora). Za razliku od materijalnog imuniteta, kod kojeg se ne odgovara za zauzeti stav, procesni imunitet regulira mogućnost pokretanja kaznenog postupka i određivanje pritvora. U nekim zemljama (primjerice u Bosni i Hercegovini) javni bilježnici ne uživaju nikakvu vrstu imuniteta te, za razliku od sudaca, mogu kazneno odgovarati za npr. zauzeti stav o nekom pravnom pitanju. Ovi javni bilježnici, osim materijalnog imuniteta, ne uživaju ni nikakav procesni imunitet. Za razliku od takvih javnih bilježnika, hrvatski javni bilježnici uživaju procesni imunitet, te je ZJB izričito propisao da javni bilježnik ne smije biti pritvoren u kaznenom postupku koji je protiv njega pokrenut zbog sumnje da je počinio kazneno djelo u obavljanju javnobilježničke službe bez dopuštenja vijeća trojice sudaca suda drugog stupnja na području kojega se nalazi sud koji vodi postupak ${ }^{31}$. Hrvatski zakonodavac je, izgleda, prepoznao važnost imuniteta javnog bilježnika, ali je, nažalost, i dalje ostao nereguliran materijalni imunitet javnih bilježnika, te isti i dalje mogu odgovarati za izraženo pravno mišljenje, odnosno za zauzeti pravni stav, što bi bila neka vrsta delikta mišljenja za koje smatramo da je relikt nekih prijašnjih vremena i kao takav stavlja javne bilježnike u neravnopravan položaj s vršiteljima ostalih pravosudnih djelatnosti, a posebice $u$ slučajevima kada javni bilježnici obavljaju povjerene poslove i kada imaju pravni položaj suca (ali ne i imunitet kao sudac).

\subsection{Građanskopravna odgovornost javnih bilježnika}

Kada govorimo o građanskopravnoj odgovornost javnih bilježnika, govorimo o odgovornosti profesionalca zbog koje isti odgovara za štetu koju počini u obavljanju svoje djelatnosti. Za razliku od stegovne, kaznene i prekršajne odgovornosti, u kojima se odgovorna osoba stavlja naspram profesionalnih udruženja, odnosno države, kod građanskopravne odgovornosti javni bilježnik odgovara izravno korisniku svojih usluga ili trećoj osobi koja pretrpi štetne posljedice proizašle iz obavljanja javnobilježničke djelatnosti ili u svezi s njom. Još jedna bitna razlika građanskopravne odgovornosti javnih bilježnika u odnosu na stegovnu, prekršajnu i kaznenu odgovornost je ta što javni bilježnik može odgovarati (građanskopravno) i za radnju druge osobe (po pravilima o odgovornosti za drugoga), dok kod ostalih vrsta odgovornosti ta mogućnost ne postoji te javni bilježnik može stegovno, prekršajno i/ili kazneno odgovarati samo za vlastite radnje, a ne i za radnje drugih osoba. Specifičnosti građanskopravne

\footnotetext{
${ }^{31}$ Čl. 40. st. 3. ZJB.
} 
odgovornosti javnih bilježnika proizlaze iz specifičnog pravnog statusa koji javni bilježnici imaju u pravnom sustavu, s posebnim naglaskom na javna ovlaštenja javnog bilježnika. Bitno je naglasiti činjenicu da u našem pravnom sustavu ne postoje posebna pravila o odgovornosti javnih bilježnika za štete koje prouzrokuju u obavljanju svoje službe ili u svezi s njom, pa se stoga na tu odgovornost primjenjuju opća pravila o odgovornosti za štetu koja su dodatno (ali vrlo malo i ni približno dovoljno) razrađena kroz sudsku praksu, koja je još uvijek nedovoljno razvijena po tom pitanju. Općenito govoreći, evidentno je da je oblast javnobilježničke odgovornosti za štetu ostala podnormirana i relativno zanemarena. Vrlo oskudna regulativa navedenih pitanja (samo dvije odredbe općeg obveznog prava reguliraju pitanja koja imaju vezu s profesionalnom odgovornošću, a ZJB sadrži samo jednu zakonsku odredbu o posebnoj odgovornosti javnih bilježnika) nije dovoljna da potpuno i na odgovarajući način uredi ovo pitanje, te bi u ovom slučaju i prenormiranost bila poželjnija od podnormiranosti zbog činjenice da je javnobilježnička profesija relativno nova pravnička profesija u RH i da će se primjenjivači prava po prvi put suočiti s pitanjima naknade štete zbog propusta u obavljanju javnobilježničke službe ${ }^{32}$. ZJB zapravo upućuje na opća pravila o odgovornosti za štetu. U Zakonu o obveznim odnosima, ${ }^{33}$ kao sankcija za povredu načela zabrane prouzrokovanja štete, propisana je obveza štetnika da štetu naknadi ako ne postoje ekskulpirajući razlozi koji variraju ovisno o tome radi li se o deliktnoj ili ugovornoj odgovornosti, objektivnoj ili subjektivnoj odgovornosti. ZOO, s iznimkom definiranja standarda dužne pažnje dobrog profesionalca (stručnjaka), ${ }^{34}$ ne sadrži posebna pravila o profesionalnoj odgovornosti, pa time ni o profesionalnoj odgovornosti javnih bilježnika. ZOO ne nabraja opće pretpostavke odgovornosti za štetu, već navodi da se za štetu odgovara po principu presumirane krivnje, da se za štetu od opasne stvari ili djelatnosti te u drugim slučajevima predviđenima zakonom odgovara bez obzira na krivnju, te propisuje da se presumira obična nepažnja. Za postanak, odnosno nastanak obveznopravnog odnosa odgovornosti za štetu potrebna je u svakom konkretnom slučaju, kumulativno, egzistencija pretpostavki za tu odgovornost. U pravnoj teoriji nema spora o opsegu i pretpostavkama odgovornosti za štetu. Pretpostavke odgovornosti za štetu su subjekti tog izvanugovornog odnosa, s jedne strane oštećenik, a s druge štetnik koji ujedno može imati obveznopravni status odgovorne osobe. ${ }^{35}$ Druga pretpostavka deliktne odgovornosti je počinjena, odnosno

\footnotetext{
${ }^{32}$ Tako: Povlakić M., Odgovornost notara..., op.cit., str. 4.

${ }^{33}$ Zakon o obveznim odnosima, Narodne novine br. 35/05, 41/08, 125/11, 78/15, u daljnjem tekstu: ZOO.

${ }^{34}$ Čl. 10. st. 2. ZOO Sudionik u obveznom odnosu dužan je u ispunjavanju obveze iz svoje profesionalne djelatnosti postupati s povećanom pažnjom prema pravilima struke i običajima (pažnja dobrog stručnjaka).

35 Štetnik i odgovorna osoba ne moraju uvijek biti ista osoba, kao što je slučaj kod odgovornosti za drugog. Najčešći slučajevi odgovornosti za drugog su slučajevi roditeljskog, skrbničkog odnosa te odnosa iz ugovora o
} 
pretrpljena imovinska i/ili neimovinska šteta. Treća je pretpostavka štetna radnja manifestirana kroz nezakonit ili nepravilan rad javnog bilježnika, a četvrta je pretpostavka kauzalni neksus, odnosno uzročno-posljedična veza između štetne radnje i nastale štete. Konačno, peta pretpostavka odštetnopravne odgovornosti je protupravnost, odnosno krivnja ako se radi o odgovornosti po osnovi krivnje, koja se dijeli na namjeru i nepažnju.

ZJB te ostali (podzakonski) propisi o javnom bilježništvu uvijek obvezuju javnog bilježnika da naknadi štetu koju je počinio u okviru obavljanja svoje djelatnosti ili u svezi s njom. Dakle, prema pravilima o odgovornosti javnih bilježnika, javni bilježnik odgovara samo za štete koje su nastale u obavljanju djelatnosti i u svezi s njom, ali ne i za štete koje je počinio javni bilježnik, ali izvan službe i bez veze s njom. Poradi ovoga, bitno je odrediti što je javnobilježnička djelatnost i kakva je njena priroda. Javnobilježnička djelatnost je pravno uređena djelatnost čija se pravila reguliraju zakonskim i podzakonskim aktima, a čiji nositelji su samostalni i neovisni nositelji javnih ovlasti, te su oni osobe javnog povjerenja ${ }^{36}$. Za javne bilježnike neki autori smatraju da su oni javni službenici, ${ }^{37}$ ali to i nije baš ispravno razmišljanje. Javni bilježnici se ne nalaze u službeničkom odnosu ni prema kome, niti prema državi koja ih je imenovala, niti prema nekoj od javnih službi. Iako javnobilježnička služba ima elemente javnosti, tj. radi se o javnoj službi, sam javni bilježnik nije ničiji službenik niti zaposlenik, on radi neovisno, u svoje ime i za svoj račun, a vezan je samo zakonskim i ustavnim odredbama, te pravilima javnog morala $^{38}$. Neki autori javno bilježništvo smatraju slobodnom profesijom koja se od sličnih profesija razlikuje utoliko što su javnim bilježnicima dane i javne ovlasti koje po svojoj prirodi pripadaju državi. Za razliku od ovih autora, smatramo da je javno bilježništvo prije svega javna služba, s elementima slobodnih profesija. No, kojem god se od ovih dvaju stavova priklonili, u svakom slučaju status javnobilježničke službe ima ove elemente: školovanom pravniku je dano javno povjerenje kako bi u javnom interesu, savjesno i pošteno obavljao poslove koje bi inače obavljala država. ${ }^{39}$ Budući da javni bilježnik u svoje ime i za svoj račun obavlja poslove koje bi mogla obavljati država, ali je procijenjeno da će osobe koje rade u svoje ime i za svoj račun te poslove obavljati brže i učinkovitije, smatra se da javni bilježnici stoga moraju samostalno

osiguranju i o radu (vidi čl. 1055. - 1062. ZOO). Također, odgovornost za drugoga može biti predviđena i nekim drugim propisom; npr. čl. 126. ZJB.

${ }^{36}$ Javnobilježničku službu obavljaju javni bilježnici kao samostalni i neovisni nositelji te službe koji imaju svojstvo osoba javnog povjerenja (čl. 2. ZJB).

${ }^{37}$ Tomić Z., Opšta javnopravna obeležja notarijata, u Javnobeležničko pravo, priredio Hiber, D., Univerzitet, Pravni fakultet, Centar za publikacije, Beograd, 2006.

${ }^{38}$ Tako: Karanikić-Mirić M., Odgovornost javnih beležnika u srpskom građanskom pravu, Pravni život, II tom, br. 10, Beograd, 2014., str. 562.

${ }^{39}$ Ibid., str. 564. 
odgovarati za eventualne štete proizašle iz njihova rada i u svezi $s$ istim, tj. oni snose građanskopravu odgovornost za nastalu štetu.

Mnogobrojna su pitanja koja se nameću uz problematiku građanskopravne odgovornosti javnih bilježnika. Tko treba nositi teret rizika nastanka štete koja je posljedica vršenja javnobilježničke službe: oštećenik, država koja je imenovala javnog bilježnika, komore koje, uz državu, nadziru rad javnih bilježnika, javni bilježnik ili pak netko treći? Posebice je složeno pitanje pravne osnove odgovornosti. ${ }^{40}$ Može li režim općeg ugovornog i deliktnog prava, odnosno klasičnih pravila o građanskopravnoj odgovornosti odgovoriti na izazove obveznog odnosa nastalog prouzročenjem štete vršenjem javnobilježničke djelatnosti? Je li javnobilježnička djelatnost opasna djelatnost, odnosno mogu li se pravila objektivne odgovornosti primijeniti na štete od takve opasne djelatnosti? Je li potrebno uvesti poseban sustav odštetne odgovornosti javnih bilježnika koji se razlikuje od režima općeg ugovornog i deliktnog prava? Postoji li pravnoteorijska i politička utemeljenost i opravdanost posebnog sustava građanskopravne odgovornosti javnih bilježnika? Pitanje građanskopravne odgovornosti javnih bilježnika sve više zaokupljaju pozornost (strane) pravne znanosti i sudske prakse, no u domaćoj je pravnoj literaturi navedenoj problematici posvećena vrlo mala, gotovo zanemariva pozornost, a sudska praksa o ovom pitanju je također vrlo slaba i s jako malim brojem odluka.

U vezi s naknadom štete od javnog bilježnika pasivno je legitimiran javni bilježnik, iako u jednom dijelu štete pasivnu legitimaciju može imati i njegov osiguratelj, čime se zapravo ne otklanja pasivna legitimacija javnog bilježnika nego se samo olakšava položaj, kako oštećenika, tako i samog javnog bilježnika, a što i jest smisao postojanja osiguranja od odgovornosti. U pogledu aktivne legitimacije za postavljanje odštetnopravnih zahtjeva prema javnim bilježnicima nisu predviđena nikakva izričita ograničenja, pa bi se iz toga moglo tumačiti da krug mogućih oštećenika uključuje sve one koji su pretrpjeli štetu od radnji javnog bilježnika, a ne samo osobe koje su neposredno sudjelovale u postupku kod javnog bilježnika. Ako oštećenik zahtijeva naknadu štete zbog radnje neke osobe za koju odgovara javni bilježnik, tada je javni bilježnik samo odgovorna osoba, ne i štetnik, a drugi subjekt koji je odgovoran za štetu je štetnik. U našim propisima nije određeno tko sve može biti oštećenik. Po prirodi stvari je to osoba kojoj je počinjena šteta i koja traži naknadu iste. U krug potencijalnih oštećenika, prije svih, svrstavaju se osobe koje su neposredno koristile usluge javnih bilježnika (razni ugovori,

\footnotetext{
${ }^{40}$ O pravnoj osnovi odgovornosti za štetu vidi: Klarić P., Odštetno pravo, Narodne novine, Zagreb, 1996., str. 1.-
} 158. 
izjave, pohrana vrijednih stvari, posvjedočenje činjenica i sl.). Pored osoba koje su neposredno koristile usluge javnih bilježnika, u krug potencijalnih oštećenika možemo svrstati i osobe u čiju su korist sastavljane isprave (npr. vlasnik nekretnine kod sastava izjave o priznanju prava vlasništva, nasljednik i legatar kod sastava oporuke, osoba kojoj se treba izvršiti neki nalog, punomoćnik kod sastava punomoći, i sl.). Nadalje, u krug potencijalnih oštećenika možemo svrstati i osobe koje nisu ni neposredno koristile usluge javnog bilježnika, niti je javni bilježnik u vezi njih sastavljao ikakvu ispravu. Ovdje možemo kao primjer navesti osobe koje su se u dobroj vjeri pouzdale $u$ točnost $\mathrm{i}$ istinitost javnobilježničke (javne) isprave, pa su zbog toga pretrpjele štetu. Ovime krug potencijalnih oštećenika nije zatvoren, te su uvijek moguće nove situacije vezano uz odgovornost za štetu, a sve iz razloga nepredvidivosti i raznovrsnosti svakodnevnih životnih situacija.

Štetna radnja se manifestira kroz nezakonit ili nepravilan rad javnog bilježnika. Pri tome valja istaknuti da se nezakonit rad očituje kao postupanje suprotno zakonu, drugom propisu ili općem aktu, ili propuštanje da se zakon, drugi propis ili opći akt, primijeni s voljom ili pristankom da se trećem nanese šteta. Nepravilan rad očituje se kao činjenje ili nečinjenje suprotno uobičajenom ili propisanom načinu obavljanja djelatnosti, a može se zaključiti o postojanju volje ili pristanka da se time oštete prava i interesi trećega. ${ }^{41}$ Štetna radnja, koja je građanski delikt, može se sastojati u činjenju ili nečinjenju. Daljnja pretpostavka odgovornosti za štetu javnih bilježnika, koja je prema nekim mišljenjima zapravo posebna pretpostavka, odnosi se na činjenicu je li štetna radnja počinjena u obnašanju dužnosti. Zapravo se radi o kvalitativno posebnom obliku štetne radnje. Štetna radnja mora biti vezana uz određeni postupak i djelovanje javnog bilježnika u okviru njegove službe ili u svezi s njom, a ne smije se raditi o takvoj radnji koja bi bila izvan obnašanja dužnosti. To može ponekad biti faktično pitanje koje zavisi od konkretnih okolnosti slučaja i ne mora biti vezano uz konkretnu radnju javnog bilježnika, već se može odnositi i na pripremne radnje, djelovanje javnog bilježnika izvan ureda, ali u svezi i u funkciji određenog javnobilježničkog postupka. Bitno je da se u odnosu na sve okolnosti može zaključiti da određeno činjenje ili nečinjenje spada u djelokrug ovlasti i nadležnosti javnog bilježnika, te je sastavni dio obnašanja njegove službe. U protivnom, sve one eventualne štetne radnje koje bi počinio javni bilježnik kao fizička osoba izvan službe i koje nisu u svezi s njom, činile bi građanskopravni delikt za koji bi konkretni javni bilježnik

\footnotetext{
${ }^{41}$ Vidi odluku Vrhovnog suda Republike Hrvatske, Rev 521/02-2.
} 
odgovarao kao i svaka druga fizička osoba po općim propisima o odgovornosti za štetu. ${ }^{42}$ Ovdje je bitno razlučiti da ,štetna radnja počinjena u obnašanju dužnosti““ nije istovjetno što i pojam „stručna pogreška“. Mnogi autori ${ }^{43}$ uz opće uvjete odgovornosti za štetu dodaju još i stručnu, odnosno profesionalnu pogrešku. U toj konstrukciji za zasnivanje profesionalne odgovornosti nije dovoljno skrivljeno prouzrokovanje štete, nego se još zahtijeva i da se postupak stručnjaka kojim je prouzrokovana šteta kvalificira kao stručna pogreška, tj. da to postupanje bude protivno pravilima odgovarajuće struke. ${ }^{44}$ Smatramo da je „stručna pogreška“ suvišan i nepotreban uvjet koji ponekad onemogućuje stvarnu naknadu štete, iz razloga jer odgovornost profesionalca i stručna pogreška ne moraju biti kumulirani. Naime, moguće je da je jedan javni bilježnik postupao lege artis, tj. da je poštivao sva pravila javnobilježničke struke, ali da je i dalje odgovoran za štetu. Npr. iako je sve radnje poduzeo sukladno propisima, moguće je da je javni bilježnik slučajno i, čak neovisno o svojoj službi, znao za stvarno stanje stvari (npr. postojanje opoziva punomoći za izvršenje posla koji se provodi kod tog javnog bilježnika). Dakle, ako bi postupao samo po zakonu, a da pritom ipak nije primjenio sva svoja znanja i saznanja koja de facto ima (saznanje da je punomoć za konkretni pravni posao o kojem sastavlja ispravu opozvana), pa makar ih i slučajno imao, smatramo da bi taj javni bilježnik i dalje morao odgovarati za prouzrokovanu štetu iako je postupao po zakonu i nije prekršio nijedan propis, a to iz razloga jer nije postupao bona fide. Iako pravila struke javnom bilježniku ne nameću obvezu provjeravanja pojedinih činjenica, te iako poštovanje pravila struke ne bi dovelo do potpunih saznanja o određenoj stvari, javnog bilježnika obvezuje ono što on ipak de facto zna ${ }^{45}$, pa je stoga moguće da javni bilježnik postupa mala fide i kad se, strogo uzevši, ne može reći da

\footnotetext{
${ }^{42}$ Slično i: Jug J., Odgovornost za štetu zbog nezakonitog ili nepravilnog rada sudaca, Zbornik Pravnog fakulteta Sveučilišta u Rijeci, v. 33, br. 1, 2012., str. 448.

${ }^{43}$ Npr., Ivana Stojanović, "Dijagnostičke lekarske greške», Pravni život 1/2010, 225., vidi također: Petar Klarić, "Autorizovano izlaganje", u: Godišnjak tribine Pravnog fakulteta u Zagrebu i Kluba pravnika grada Zagreba, Bilten br. 2 (ur. Jakša Barbić), Pravni fakultet u Zagrebu, Zagreb, 2002., str. 46. O neosnovanom ubrajanju stručne (lekarske) greške među uslove za zasnivanje građanske odgovornosti za štetu pričinjenu obavljanjem medicinske delatnosti i o specifičnom odnosu pojmova profesionalne krivice i stručne greške u srpskom pravu vid., umesto svih, Miodrag V. Orlić, "Zakon o zdravstvenoj zaštiti i odgovornost lekara za prouzrokovanu štetu", poseban otisak iz časopisa Pravm' život 7-8/2012, Udruženje pravnika Srbije, Beograd 2012, Lj. Dabić, "Profesionalna odgovornost nosilaca slobodnih profesija", Pravo i privreda 7-9/2010., 54., K. Ivančević, "Osiguranje javnih beležnika od profesionalne odgovornosti”, Evropska revija za pravo osiguranja 2/2012, 68., sve prema: KaranikićMirić M., Odgovornost javnih beležnika..., op. cit., str. 579.

${ }^{44}$ Loc.cit.

${ }^{45}$ Ovakav stav je kod nas utemeljen samo na općim pravilima građanskog prava, posebice na načelu savjesnosti i poštenja. Za razliku od naših propisa, Njemačka Savezna uredba o javnim bilježnicima izričito propisuje da, unatoč činjenici da u konkretnoj radnji nije ovlašten ulaziti u sadržaj isprave, nego samo npr. ovjerava potpis ili paraf, javni bilježnik mora odbiti obaviti tu službenu radnju, ako ima saznanja o npr. nedozvoljenosti i/ili nesavjesnosti tog pravnog posla, iako postupajući samo lege artis, on ne bi počinio nikakvu grešku. Ovdje se vidi važnost postupanja javnog bilježnika i bona fide, a ne samo lege artis. Vidi § 32 st. 2., te $§ 14$ st. 2. navedene uredbe.
} 
postupa contra legem artis. ${ }^{46}$ Postupanje contra legem artis je indikator krivnje, ono nagovještava krivnju, ali postupanje lege artis u najužem smislu još uvijek ne znači da krivnje i odgovornosti za štetu nema. ${ }^{47}$

Smatramo da javnobilježnička djelatnost sadrži veliki štetni potencijal, tj. vršenje iste predstavlja povećanu opasnost po imovinu ljudi, odnosno po pravni poredak bez obzira na to koliko se pažljivo ista vrši, pa da je zbog toga javnobilježnička djelatnost opasna djelatnost. Zbog toga smatramo da je objektivna (kauzalna) odgovornost javnih bilježnika pravilan put u razvoju građanskopravne odgovornosti javnih bilježnika, no o opasnosti javnobilježničke djelatnosti i objektivnoj odgovornosti javnih bilježnika nećemo detaljnije govoriti u ovome radu, obzirom da je ista predmet jednog šireg rada istoga autora.

O prirodi odgovornosti javnih bilježnika vode se mnoge polemike. Neki autori ${ }^{48}$ smatraju da se kod odgovornosti javnih bilježnika uvijek radi o ugovornoj odgovornosti, neki autori ${ }^{49}$ smatraju da se radi o kombinaciji ugovorne i izvanugovorne (deliktne) odgovornosti, dok neki autori ${ }^{50}$ smatraju da odgovornost javnih bilježnika može imati isključivo obilježja izvanugovorne (deliktne) odgovornosti. Razmišljanje da odgovornost javnih bilježnika može imati isključivo obilježja izvanugovorne (deliktne) odgovornosti autor Leș opravdava činjenicom da javnobilježničke radnje zapravo predstavljaju radnje države, odnosno državnih tijela, iako javni bilježnici djeluju samostalno. Iako smo mišljenja da javnobilježnička odgovornost može imati određene elemente (obilježja) ugovorne odgovornosti, ipak smatramo da se tu radi o deliktnoj odgovornosti. Trenutno stanje legislative, u pravilu, ne zahtijeva da se između javnog bilježnika i stranke zaključuje bilo kakav ugovor. Stoga je problem osnove građanskopravne odgovornosti javnih bilježnika vrlo delikatno pitanje. Po našem mišljenju bi se na javnobilježničku odgovornost za prouzrokovane štete uvijek trebala primjeniti pravila o deliktnoj odgovornosti, bez obzira što javnobilježnička odgovornost može imati i neka obilježja ugovorne odgovornosti,

\footnotetext{
${ }^{46}$ Karanikić-Mirić M., Odgovornost javnih beležnika..., op. cit., str. 580.

${ }^{47}$ Loc. cit.

${ }^{48}$ Durry G., La distinction de la responsabilité contractuelle et la responsabilité delictuellé, Universitete Me Gill, str. 168., prema: Selimović M., Odgovornost i osiguranje notara za štetu pričinjenu klijentu u obavljanju djelatnosti, Brčko, 2014., str. 99.

${ }^{49}$ Salma J., Notarijalno obligaciono pravo, Zbornik radova Pravnog fakulteta Novi Sad, vol. 46, broj 1, 2012. , str. 99.; Rijavec V., Građanskopravna odgovornost javnih bilježnika, Zbornik radova s trinaestog međunarodnog savjetovanja Aktualnosti građanskog i trgovačkog zakonodavstva i prakse, Pravni fakultet Mostar, 2015., str. 15.16.

${ }^{50}$ Tako: Leș I., u: Elemente de drept notarial, Ediția 3, C. H. Beck Publishing House, Bucharest, 2014., prema: Roşu C., Liability of the notary public for notarial authentic documents, Faculty of Law, West University Timişoara, Romania, Curentul juridic, 2015., str. 118.; Karanikić-Mirić M., Odgovornost javnih beležnika..., op. cit., str. 569.-570.
} 
osim ako će po njima u konkretnom slučaju oštećenik teže doći do naknade štete. Naime, iako javnobilježnička odgovornost često ima obilježja ugovorne odgovornosti, smatramo da se tu zapravo radi samo o prividnoj ugovornoj odgovornosti jer javni bilježnik svoje radnje, odnosno ovlaštenja za iste ne crpi iz ugovora sa strankom, nego isključivo iz ovlaštenja dodijeljenih mu zakonom. Stoga, iako se ponekad čini da nastaje ugovor između javnog bilježnika i stranke, ipak povredom svoje ,ugovorne“ obveze javni bilježnik zapravo čini delikt. Javni bilježnik prilikom vršenja svoje službe ima javnopravnu dužnost poduzimanja službene radnje, i to nepristranog poduzimanja iste, koju može odbiti poduzeti samo iznimno. Javni bilježnik sa strankom nije vezan ugovornim odnosom nego ga obvezuju upravo njegova javnopravna ovlaštenja i propisi, a posebice načelo savjesnosti i poštenja, te je stoga javni bilježnik manje slobodan u svojem postupanju nego li je to, primjerice, odvjetnik. Upravo ovdje dolazi do izražaja priroda javnobilježničke službe kao javne službe, te iz toga proizlazi da se građanskopravna odgovornost javnih bilježnika treba ocjenjivati po pravilima izvanugovorne, odnosno deliktne odgovornosti. Nadalje, bitan argument u korist primjene pravila o deliktnoj (izvanugovornoj) odgovnosti je i nemogućnost odbijanja izvršenja službene radnje. Naime, javni bilježnik ne može birati hoće li izvršiti radnju čije izvršenje je od njega stranka zatražila, nego je javni bilježnik, kao nositelj javnih ovlaštenja, obvezan traženu radnju izvršiti, a odbiti je može samo iz zakonom propisanih razloga. Iz ovoga je vidljiva činjenica da javni bilježnik svoje radnje vrši prvenstveno na temelju obvezujućih propisa koje je dužan poštovati, pa eventualnim kršenjem istih nastaje delikt, te posljedično i deliktna odgovornost za štetu. Štoviše, kod javnobilježničkih radnji nema mogućnosti proširiti, ograničiti ili isključiti odgovornost javnog bilježnika, a što bi bilo bitno obilježje ugovornog odnosa, a samim time i ugovorne odgovornosti. S obzirom da čak i ZOO dopušta ${ }^{51}$ alternativnu primjenu pravila o ugovornoj i izvanugovornoj (deliktnoj) odgovornosti, smatramo da treba ostaviti otvorenu mogućnost odgovornosti javnih bilježnika i po pravilima o ugovornoj odgovornosti, iz razloga jer ponekad neće biti moguće dobiti naknadu štete samo uz primjenu pravila o deliktnoj odgovornosti. ${ }^{52}$ Ostavljanjem mogućnosti traženja naknade štete i prema pravilima o ugovornoj i prema pravilima o deliktnoj odgovornosti se zapravo stvara mogućnost da stranka dobije naknadu štete, iako to ne bi bilo moguće prema pravilima samo jednog od ova dva režima odgovornosti. Građanskopravna odgovornost javnih bilježnika je vrlo kompleksna i opsežna tema koja

\footnotetext{
${ }^{51} \check{C}$ l. 349. ZOO.

${ }^{52}$ Npr. različiti su zastarni rokovi jer se kod ugovorne odgovornosti zastarni rokovi računaju prema pravilima za pojedini ugovor, dok se kod deliktne odgovornosti isti računaju prema pravilima o zastari naknade štete.
} 
iziskuje znatno detaljnije istraživanje nego li je to moguće u kratkoj formi kao što je ova, zbog čega je ista predmet doktorske disertacije autora ovog rada.

\section{Zaključak}

Profesionalna odgovornost javnih bilježnika je specifična, kao što je i sama javnobilježnička služba specifična. S obzirom da u hrvatskom javnobilježničkom pravu trenutno ne postoji poseban sustav profesionalne odgovornosti javnih bilježnika, eventualni postupci za utvrđivanje pojedine vrste profesionalne odgovornosti se rješavaju po općim propisima, pritom primjenjujući određene posebnosti koje su propisane za javne bilježnike. Kroz ovaj rad smo ukratko predstavili svoja razmatranja profesionalne odgovornosti javnih bilježnika te smo objasnili vrste te odgovornosti. Utvrdili smo kako su pojedine iznimke od općih pravila, koje su propisane isključivo za javne bilježnike, najčešće lošije od općih propisa, a ponegdje su i možebitno protuustavne. Smatramo da bi sudovi morali imati aktivniju ulogu i znatno „hrabriji“ pristup u primjeni i tumačenju odredbi o profesionalnoj odgovornosti javnih bilježnika. Očekujemo da sudska praksa može odigrati jako važnu ulogu u razvoju instituta profesionalne odgovornosti javnih bilježnika. U ovom smo radu istaknuli kako smatramo da je objektivna (kauzalna) odgovornost javnih bilježnika primjerena društvenoj važnosti javnobilježničke službe i potencijalnoj opasnosti koja proizlazi iz vršenja te službe, te je stoga ista pravilan put u razvoju građanskopravne odgovornosti javnih bilježnika. Zadatak pravnog poretka je, između ostaloga, kontinuirano razvijati i jačati mjere nadzora nad javnim bilježnicima i stvarati što strože (prevencijske) propise koji će se baviti pitanjima sigurnosti pravnog prometa, odnosno prevencijom šteta od javnobilježničke djelatnosti i u svezi s njom. Nakon što smo dali kratak prikaz profesionalne odgovornosti javnih bilježnika, preostaje nam samo vidjeti kako će se ova profesionalna odgovornost razvijati u budućnosti. 
PROFESSIONAL LIABILITY OF PUBLIC NOTARIES IN THE REPUBLIC OF

CROATIA - DISCIPLINARY, CRIMINAL, MISDEMEANOR AND CIVIL

\section{LIABILITY}

Summary: According to Art. 2 of the Law on Public Notary, public notary services are performed by public notaries as independent service holders who have the capacity of public trust. Thus, public notaries are impartial advisors to the parties, impartial writers of their will, giving them the character of the authentic act and the power of the executive judicial verdict while taking care to prevent the occurrence of disputes between the participants of the notarial procedure. Due to the high set of conditions for appointing a public notary, the expertise of public notaries and their permanent professional development, there are high expectations in the quality of their work and the establishment of legal certainty before the notaries. Because of this it is expected that public notaries will not make a mistake in their work, and if they do, they will have full professional responsibility. Notaries can have professional liability in many different ways. Due to the short form, in this paper we will only give a short overview of the professional liability of public notaries. In general terms, the issue of professional liability is devoted to relatively few systematic research in our legal literature, which is not surprising because of the complexity and multidimensionality of the problem.

Key words: public trust, professional liability, dispute prevention, disciplinary responsibility, misdemeanor liability, criminal liability, civil liability. 